\title{
Modern trends of the international labor force migration
}

\author{
Oleksandr Chernyak $^{1, *}$, and Yevgen Chernyak $^{2}$ \\ ${ }^{1}$ Taras Shevchenko National University of Kyiv, Department of Economic Cybernetics, 90-a, Vasylkivska str., Kyiv, 03022, Ukraine \\ ${ }^{2}$ Taras Shevchenko National University of Kyiv, Department of International Economics and Marketing, 90-a, Vasylkivska str., Kyiv, \\ 03022, Ukraine
}

\begin{abstract}
The modern trends of the international labor force migration and the main migration corridors are analyzed in the paper. According to the United Nations Department of Economic and Social Affairs, in 2017, the global stock of international migrants (including refugees) was an estimated 258 million. Inequality between supply and demand on the labor market is a main problem of modern international migration processes. It is possible to make a conclusion about the global increase of amounts of labor migration all over the world, in all the countries and regions. The main trends of remittance flows are also studied. The amount of remittances in 2018 was $\$ 689$ billions. And $\$ 518$ billions were sent to the developing countries. In relative terms, remittances in nine countries accounted for over a fifth of the gross domestic product (GDP) in 2018; in the case of Tonga, remittances represented $36 \%$ of the country's GDP. As a conclusion, it should be said that the amount of remittances is an important macro economical figure. Its inflow can ensure the increase of foreign currency's supply in the country.
\end{abstract}

\section{Introduction}

One of the most important features of globalization is the intensification of international labor force migration. International labor force migration is a transborder movement of workers for a period longer then one year to employ out of country of origin. Such kind of migrants are able to have stable connections with their country of origin.

It is very hard to separate the early named types of international migration. According to the International Labor Organization's convention, "migrant worker" is a person, which is migrating (or migrated) from one country to another looking for a job. This definition covers not all the categories of migrants. Such persons as seasonal workers, border workers and freelancers are not counted here. These statistical errors are artificially reducing the total amount of the international labor force migration. But even this approach shows a large economical effect of the labor force migration on the country of origin and the destination country.

Nowadays main international labor migration flow directions are:

- From the developing countries to the developed countries;

- Between developing countries;

- Between developed countries;

- From postsocialistic countries to developed countries;

- Migration of scientists and high-skilled works from developed countries to developing countries.

Unsatisfying level of personal welfare is a key economical factor, which increases an amount of the international labor force migration. That explains the fact, that the most of international migrants are designated from the developing countries and the countries with transitive economies. The necessity of paying for medical services, education, consumer goods and utilities forces people to look for the job in the countries with higher level of economical development. Nowadays even the least prestige position in USA or Canada or EU countries can give an income level, which is higher than the salary of chief executives in the developing countries.

The country's economical level and the level of the social security is very easy to define according to the amount and directions of international migration. As a rule, the decision to migrate can be done under the influence of the list of factors. There are two types of them: subjective and objective. The nature of peoples' needs, they are trying to satisfy using migration, has an internal origin.

According to the reports of international organizations, an average salary in the country with a high income level can be 5 time higher than in the country with a low income level. This proportion can often reach 10 times size. For example, the level of salaries of Ukrainian immigrants, which are working abroad in the sphere of agriculture, is 2 or 3 times higher than in Ukraine; for our immigrants, which are providing construction services and working as drivers the level of salaries is 10-12 times higher. As for high-skilled workers, scientists, doctors and sailors this figure can be 15-40 times higher. The expected salaries for Ukrainian immigrants are: $\$ 1800$ for doctors, $\$ 1700$ for students, $\$ 1400$ for managers and $\$ 1000$ for less qualified workers and self-employed workers. On practice, most Ukrainian immigrants are working not in their speciality, in some cases illegally. According to that, the amount of their

* Corresponding author: chernyak@univ.kiev.ua 
salaries is much less than it was expected. But even in that case, that earn much more money than in Ukraine.

Among the factors of the cultural environment, influencing the increase of the immigrants flow, it is important to name racial and ethnical discrimination and the lack of freedom of speech and choose of the confession. The mass return of ethnical Ukrainians that were earlier deported during the Soviet period can be named as an example.

The intensiveness of the international labor force migration is also can be influenced by the special features of the political system, democracy rate, authorities' corruption rate and the country's ecological conditions (an access to the clear water, availability of qualitative food).

The processes of international labor force migration in Ukraine are poorly studied and the attention of scientists and government should be paid to them. At the same time there are worldwide-known models of regulation of international labor force migration (C. Dustmann, T. Frattini [1], M. Kahanec, K. Zimmermann [2], A.M. Kim [3], D. Ratha et al. [4-7], A. Zaiceva, K. Zimmermann et al.[8, 9].

The most part of major characteristics of labor force migration were studied and described by Ukrainian researchers A. Gaidutskiy [10], E. Libanova [11], O. Malynovska [12,13], O. Chernyak [14] but there are some important aspects like evaluation of influence of labor force flow on main economical figures, the implementation of foreign experience in governmental regulation of those processes, solving problems of regions, influenced by labor force inflow and outflow, development of informational and statistical support system that must be taken into account.

\section{The main migration trends}

Modern international labor force migration has such trends:

- great influence of demographical situation on international labor force migration;

- involvement of the larger number of countries in the international labor force migration processes;

- the increase of number of categories of international labor migrants and appearance of the new types of migration;

- the increase of number of illegal migrants;

- gradual increase of number of the high-skilled migrants;

- intensification of the international labor force migration due to the increase of number of migrants and the speed of their movement.

In 2015, there were an estimated 244 million international migrants globally $(3.3 \%$ of the world's population) - an increase from an estimated 155 million people in 2000 (2.8\% of the world's population) [15].

The United Nations Department of Economic and Social Affairs reported that the total amount of international migrants all over the world rose to 258 million in 2017, from 172 million in 2000. The share of international migrants in the world's total population increased modestly, from $2.8 \%$ to $3.4 \%$, in the same period. The high-income countries are the destination countries for three-quarters of international migrants. The share of international migrants in these countries increased to $14 \%$ from $9.6 \%$ [16].

The labour force in more developed countries is projected to remain at about 600 million until 2050, while the labor force in less developed countries is expected to increase from 2.4 billion in 2005 to 3 billion in 2020 and 3.6 billion in 2040 [17].

Comparing to the Migration and Remittances Factbook 2016 (World Bank), the top ten of destinations for international labour migrants did not changed dramatically. The United States is still leading; Germany holds the second place (mostly because of hosting refugee arrivals) and Saudi Arabia takes third. The Russian Federation and the United Kingdom are also in the top five. On other hand, when international migrants are measured as a share of population, the list of leading destination countries is totally different. According to that approach, United Arab Emirates, Kuwait and Qatar are at the top. There are more than eight migrant workers for every adult native person in these countries [18].

The voluntary return of Mexicans from the United States caused a significant decline in the total amount of Mexican emigrants from 13.2 million in 2013 to 11.9 million in 2017 [19].

\section{The main migration corridors}

The migrants' countries of origin and regions, from where they come from, are changing nowadays. That is why the main ways of migration should be mentioned. According to economical reasons, migration flows from the countries with lower personal income rates to the countries with higher personal income.

Due to the modern approach, proposed by International Organization for Migration (IOM), all countries are divided into two separate groups: „South” and „North”. „North" includes countries with a high personal income level, on other hand countries with middle and low levels of personal income are named „southern". According to this categorization, international labor force migration includes four main pathways: „North” - „South” (5\% of all international labor migrants), „North” - „North” (22 \%), „South” „North” (40 \%) and „South”- ,South” (33 \%) [20].

There are three major approaches for dividing countries into groups: according to the World Bank classification, according to the United Nations Department of Economic and Social Affairs (UN DESA) and according to the United Nations Development Programme (UNDP) [20]. The difference between these approaches is in identifying the countries belonging to the „North” (Table 1).

World Bank's report accentuates 70 countries with the highest income level and names them „northern”. The UN DESA subsumes only 56 countries to this group, not taking into account the OECD countries, like Chile, Israel, Mexico, South Korea and Turkey and such developed countries as Bahrain, China, Puerto-Rico and 
UAE. The third approach, proposed by UNDP, is based on Human development Index (HDI). The 42 countries with the highest rate of Human development Index are recommended to be named „,northern”.

Table 1. 'North' and 'South' as defined by UN DESA, the World Bank and UNDP, 2010.

\begin{tabular}{|c|c|c|}
\hline UN DESA & World Bank & UNDP \\
\hline $\begin{array}{l}\text { 'South' includes five } \\
\text { developing regions: } \\
\text { Africa; the Americas } \\
\text { (excluding Northern } \\
\text { America); the Caribbean; } \\
\text { Asia (excluding Japan); } \\
\text { and Oceania (excluding } \\
\text { Australia } \\
\text { and New Zealand). }\end{array}$ & $\begin{array}{l}\text { 'South' includes low- } \\
\text { and middle-income } \\
\text { countries. }\end{array}$ & $\begin{array}{l}\text { 'South' includes } \\
\text { countries ranking } \\
\text { low, medium and } \\
\text { high on the HDI. }\end{array}$ \\
\hline $\begin{array}{l}\text { 'North' includes } \\
\text { countries/territories in the } \\
\text { developed regions: } \\
\text { Albania; Andorra; } \\
\text { Australia; Austria; } \\
\text { Belarus; Belgium; } \\
\text { Bermuda; Bosnia } \\
\text { andHerzegovina; } \\
\text { Bulgaria; Canada; } \\
\text { Channel Islands; Croatia; } \\
\text { CzechRepublic; } \\
\text { Denmark; Estonia; Faeroe } \\
\text { Islands; Finland; France; } \\
\text { Germany; Gibraltar; } \\
\text { Greece; Greenland; Holy } \\
\text { See; Hungary; Iceland; } \\
\text { Ireland; Isle of Man; } \\
\text { Italy; Japan; Latvia; } \\
\text { Liechtenstein; Lithuania; } \\
\text { Luxembourg;Malta; } \\
\text { Monaco; Montenegro; } \\
\text { Netherlands; New } \\
\text { Zealand; Norway; } \\
\text { Poland; Portugal; } \\
\text { Republic of Moldova; } \\
\text { Romania; Russian } \\
\text { Federation; Saint } \\
\text { Pierreand Miquelon; San } \\
\text { Marino; Serbia; Slovakia; } \\
\text { Slovenia; Spain; Sweden; } \\
\text { Switzerland; The } \\
\text { formerYugoslav Republic } \\
\text { of Macedonia; Ukraine; } \\
\text { United Kingdom of Great } \\
\text { Britain and Northern } \\
\text { Ireland; and the United } \\
\text { States of America. }\end{array}$ & $\begin{array}{l}\text { 'North' includes high- } \\
\text { income } \\
\text { countries/territories: } \\
\text { Andorra, Aruba; } \\
\text { Australia; Austria; } \\
\text { Bahamas; Bahrain; } \\
\text { Barbados; Belgium; } \\
\text { Bermuda; Brunei } \\
\text { Darussalam; Canada; } \\
\text { Cayman Islands; } \\
\text { ChannelIslands; } \\
\text { Croatia; Curaçao; } \\
\text { Cyprus; Czech } \\
\text { Republic; Denmark; } \\
\text { Equatorial Guinea; } \\
\text { Estonia; Faeroe } \\
\text { Islands; Finland; } \\
\text { France; French } \\
\text { Polynesia; Germany; } \\
\text { Gibraltar; Greece; } \\
\text { Greenland; Guam; } \\
\text { HongKong, China; } \\
\text { Hungary; Iceland; } \\
\text { Ireland; Isle of Man; } \\
\text { Israel; Italy; Japan; } \\
\text { Kuwait; Liechtenstein; } \\
\text { Luxembourg; Macao, } \\
\text { China; Malta; Mariana } \\
\text { Islands; Monaco; } \\
\text { Nethe Virgin Islands } \\
\text { (US). } \\
\text { Caledonds; New } \\
\text { NewZealand; Norway; } \\
\text { Oritain and Northern } \\
\text { Islands; United Arab } \\
\text { Emirates; United } \\
\text { Portugal; Republic of } \\
\text { Korea; PuertoRico; } \\
\text { Qatar; Saint Maarten } \\
\text { (Dutchpart); San } \\
\text { Marino; Saudi Arabia; } \\
\text { Singapore; Slovakia; } \\
\text { Slovenia; Spain; St } \\
\text { Martin (French part); } \\
\text { Tweden; Switzerland; } \\
\text { Turks and Caicos } \\
\text { Indom of }\end{array}$ & $\begin{array}{l}\text { 'North' include } \\
\text { countries/territories } \\
\text { ranking very highon } \\
\text { the HDI: Andorra; } \\
\text { Australia; Austria; } \\
\text { Bahrain; Barbados; } \\
\text { Belgium; Brunei } \\
\text { Darussalam; Canada; } \\
\text { Cyprus; Czech } \\
\text { Republic; Denmark; } \\
\text { Estonia; Finland; } \\
\text { France; Germany; } \\
\text { Greece; HongKong, } \\
\text { China; Hungary; } \\
\text { Iceland; Ireland; } \\
\text { Israel; Italy; Japan; } \\
\text { Liechtenstein; } \\
\text { Luxembourg; Malta; } \\
\text { Netherlands; New } \\
\text { Zealand; Norway; } \\
\text { Poland; Portugal; } \\
\text { Qatar; Republic of } \\
\text { Korea; Singapore; } \\
\text { Slovakia; Slovenia; } \\
\text { Spain; Sweden; } \\
\text { Switzerland; United } \\
\text { Arab Emirates; } \\
\text { United Kingdomof } \\
\text { Great Britain and } \\
\text { Northern Ireland; an } \\
\text { the United States } \\
\text { ofAmerica. }\end{array}$ \\
\hline
\end{tabular}

Sources: [20].

This index is a comparative rate for country's functioning effectiveness measuring. It includes quality of the healthcare, the lifetime length, the educational level and the personal income level. It should be mentioned, that HDI does not take into account an inequality of countries. It is especially about countries' size and number of population. To deal with this error an Adjusted Human development Index was developed in 2010 [20]. In a case of absolute equality of countries this index is equal to HDI and when the inequality growth, the Adjusted Human development Index is getting lower than HDI.

In each of the pathways main international labor force migration corridors must be named. For the pathway „North” - „North” these corridors are: from Germany to USA, from Great Britain to Australia, from Canada to USA. The most popular corridors on the pathway „South” - „South” are: from Ukraine to Russian Federation, from Russian Federation to Ukraine and from Kazakhstan to Russian Federation. International labor force migration from Mexico to USA and from Turkey to Germany is a most typical example of „South" - „North” migration. And, finally, on the pathway „North” - „South” most international migrants travel from USA to Mexico, from USA to South Africa and from Germany to Turkey [20].

Most international labor migrants are men. Also an important fact is that workers, travelling „South”, are mostly younger. On other hand, international labor migrants to the ,northern” countries send a larger amount of remittances to the countries of origin.

Inequality between supply and demand on the labor market is a main problem of modern international migration processes. This situation is making pressure on countries of destination of labor migrants and on their countries of origin. The determination of connection between supply and demand on labor market is one of the most important aspects of governmental regulation of the labor force migration. The existence of this connection will guarantee the increase of effectiveness of labor mobility management and ensure the fact, that workers' qualification will be applied in the spheres, where it is really necessary now. According to this, one of the main goals, which should be achieved by the governments, is a reliable estimation of capacity of the national labor market. Also the regulation of labor inflow and outflow should be done.

\section{Remittance trends}

Remittances are a key factor of the international labor force migration influencing the type of economical growth in the less developed countries.

The amount of remittances in 2018 was $\$ 689$ billions (Table 2). And $\$ 518$ billions were sent to the developing countries. This figure is $10.7 \%$ higher than in 2017 ( $\$ 468$ billions). Comparetively to 2017 the total amount of remittances has decreased for $10.3 \%$ ( $\$ 625$ billions). Remittance flows rose in all six regions, notably in Europe and Central Asia (20\%) and South Asia (14\%).

The forecasted rate of the remittances for 2019 is $\$ 715$ billions (\$538 billions will be sent to the 
developing countries). It is $3.7 \%$ higher than in 2018 [7].

Table 2. The amounts of remittances (US\$ billions).

\begin{tabular}{|l|r|r|r|r|r|r|r|l|}
\hline Year & 2012 & 2013 & 2014 & 2015 & 2016 & 2017 & 2018 & $2019 \mathrm{f}$ \\
\hline $\begin{array}{l}\text { Total } \\
\text { amount of } \\
\text { remittances }\end{array}$ & 533 & 573 & 598 & 592 & 586 & 625 & 689 & 715 \\
\hline $\begin{array}{l}\text { Increase } \\
\text { rate (\%) }\end{array}$ & 4,1 & 7,5 & 4,3 & $-1,0$ & $-1,0$ & 6,6 & 10,3 & 3,7 \\
\hline
\end{tabular}

Source: $[4,5,6,7]$.

In 2018 the remittances receiving countries' top looks that way: India (more than $\$ 79.5$ billions), China (\$67.4 billions), Philippines ( $\$ 33.7$ billions), Mexico (\$33.7 billions), Egypt (\$25.7 billion), Nigeria (\$25.1 billions), Pakistan (\$20.9 billions), Ukraine ( $\$ 16.5$ billion), Vietnam ( $\$ 15.9$ billions), Bangladesh (\$15.9 billions) (Fig. 1).

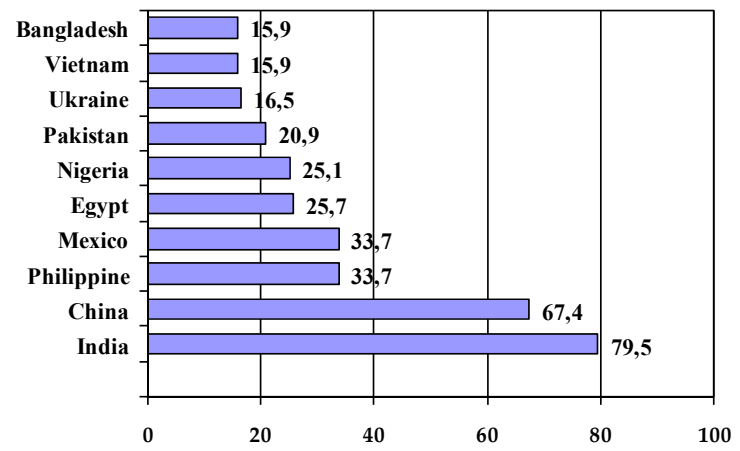

Fig. 1. Top - 10 remittances-receivers countries in 2018 (US\$ billions). Source: [7].

This trend persists for last four years in six leading countries. The data for 2017 is illustrated on Fig. 2.

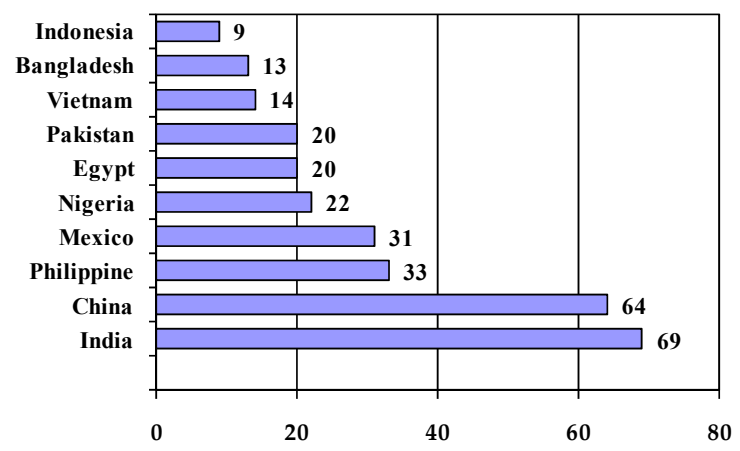

Fig. 2. Top - 10 remittances-receivers countries in 2017 (US\$ billions). Source: [6].

The significant feature of the top ten in 2018 is an improvement of positions of the Asian countries (Philippines, Pakistan, Vietnam, Bangladesh), Mexico and Egypt. Such situation can be explained by the qualitative changes in governmental regulation of the labor force migration in mentioned countries. The implementation of the visa-free regime between Ukraine and E.U. countries resulted in the increase of the amount of Ukrainian labor migrants in the European Union and the remittances inflow to the Ukrainian economy. This situation allows Ukraine to reach the eighth place in the top ten.

In relative terms, remittances in nine countries accounted for over a fifth of the gross domestic product (GDP) in 2018: Tonga (35.9 \%), Kyrgyz Republic (35.1\%), Tajikistan $(32.2 \%)$, Nepal (30.1\%), Haiti $(26.5 \%)$, Yemen $(24.2 \%)$, West Bank and Gaza (21.3\%), Gambia (20.5\%), Moldova (20.5\%) (Fig. 3).

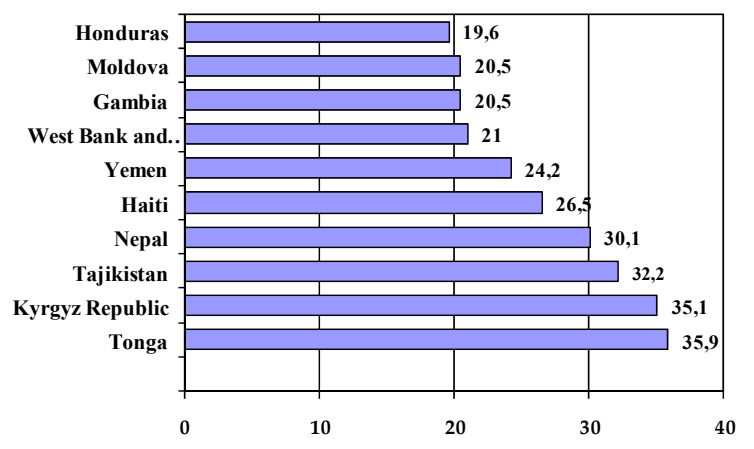

Fig. 3. The biggest remittances' receivers in 2018 (\% of remittances in GDP). Source: [7].

The top nine of countries due to the share of the received remittances in GDP in 2017 was almost similar to the new edition: Kyrgyz Republic (35\%), Tonga (33\%), Tajikistan (31\%), Haiti (29\%), Nepal (29\%), Liberia (27\%), Comoros (21 \%), Gambia (21\%), Moldova (20\%) (Fig. 4).

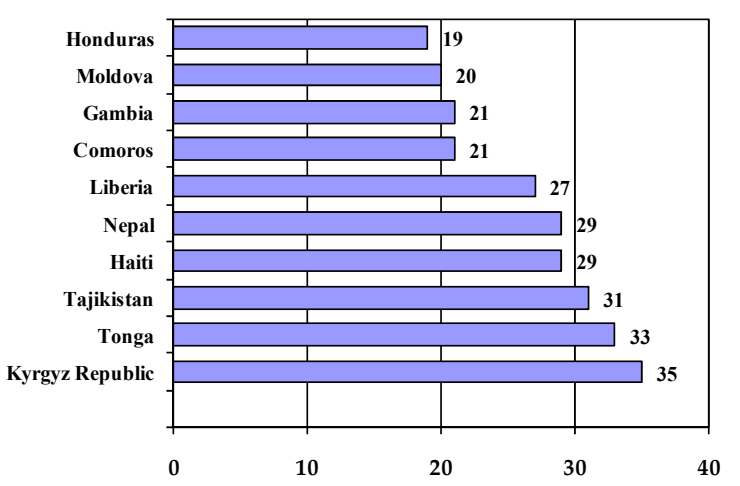

Fig. 4. The biggest remittances' receivers in 2017 (\% of remittances in GDP). Source: [6].

In the top ten of remittance-receiving countries from Eastern Europe and former Soviet Union are: Ukraine (\$16.5 billion), Russian Federation (\$9.3 billion), Romania ( $\$ 5.5$ billion), Serbia ( $\$ 4.6$ billion), Uzbekistan (\$3.4 billion), Kyrgyz Republic ( $\$ 2.7$ billion), Tajikistan ( $\$ 2.5$ billion), Bulgaria ( $\$ 2.2$ billion), Bosnia and Herzegovina ( $\$ 2.2$ billion), Georgia (\$2.1 billion) [7]. In case of Ukraine, it is about $13.8 \%$ of GDP (Fig. 5).

The economic growth in the E.U. countries, Russian Federation and the United States caused the rebound of remittance flows. The anti immigration sentiments and the tightening of immigration policies in remittance source countries are remaining the long-term risks.

As a conclusion, it should be said that the amount of remittances is an important macro economical figure. Its 
inflow can ensure the increase of foreign currency's supply in the country.

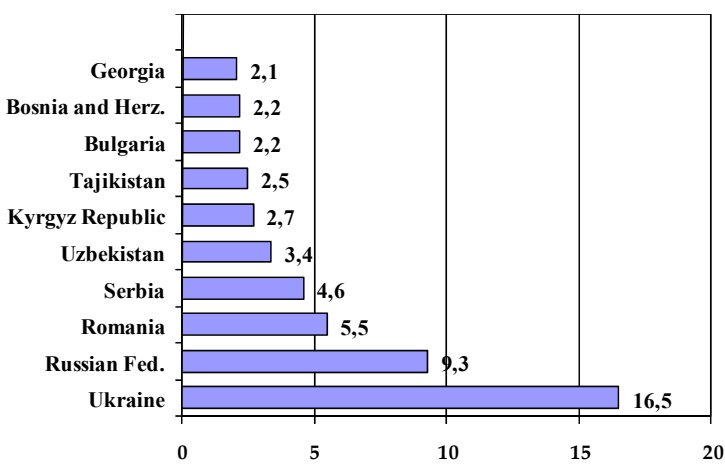

Fig. 5. Top-10 remittances' receivers among Eastern European and former Soviet countries 2018 (US\$ billions). Source: [7].

One of the most important factors influencing international competitiveness of the national economy is international labor force migration. That is because regulation of the labor force migration is among the main goals of any government. The control and limitation of the migrants' stock will cause the decrease of unemployment rate and increase of competitiveness of the national enterprises. The complex of recommendations for development of the governmental regulation of the international labor force migration is designed in the paper [21].

\section{References}

1. Dustmann, C., Frattini, T.: Immigration: The European Experiencen. IZA Discussion Paper. 6261. Institute for the Study of Labor, Bonn (2011)

2. Kahanec, M., Zimmermann, K.F.: High-Skilled Immigration Policy in Europe. IZA Discussion Paper. 5399. Institute for the Study of Labor, Bonn (2010)

3. Kim, A.M.: Foreign Labour Migration and the Economic Crisis in the EU: Ongoing and Remaining Issues of the Migrant Workforce in Germany. IZA Discussion Paper. 5134. Institute for the Study of Labor, Bonn (2010)

4. Ratha, D., Supriyo De, Dervisevic, E., Plaza, S., Schuettler, K., Shaw, W., Wyss, H., Yi, S., Yousefi, S.R.: Migration and Remittances: Recent Developments and Outlook. Special Topic: Financing for Development. Migration and Development Brief. 24. World Bank Group, Washington (2015)

5. Ratha, D., Supriyo De, Plaza, S., Schuettler, K., Shaw, W., Wyss, H., Soonhwa Yi: Migration and Remittances - Recent Developments and Outlook. Migration and Development Brief. 26. World Bank Group, Washington (2016)

6. Ratha, D., Supriyo De, Schuettler, K., Seshan, G., Yameogo, N.D.: Migration and Remittances Recent Developments and Outlook. Special Topic:
Transit Migration. Migration and Development Brief. 29. World Bank Group, Washington (2018)

7. Ratha, D., Supriyo De, Seshan, G., Yameogo, N.D., Plaza, S., Kim, E.J.: Migration and Remittances Recent Developments and Outlook. Migration and Development Brief. 30. World Bank Group, Washington (2018)

8. Zaiceva, A., Zimmermann, K.F.: Migration and the Demographic Shift. IZA Discussion Paper. 8743. Institute for the Study of Labor, Bonn (2014)

9. Zimmermann, K. F., Bonin, H., Fahr, R., Hinte, H.: Immigration Policy and the Labor Market: The German Experience and Lessons for Europe. Springer Verlag, Berlin (2007)

10. Gaidutskiy, A.: Migration Capital in Ukraine. Infosystems, Kyiv (2009)

11. Libanova, E.M.: External Labor Migration of Ukrainians: Scale, Causes, Consequences. Demography and Social Economy. 2 (33), 11-26 (2018)

12. Malynovska, O.A.: Labor Migration: social consequences and ways of responding. National Institute for Strategic Studies, Kyiv (2011)

13. Malynovska, O.A.: Migration Policy: Theoretical Approaches and Directions of Scientific Analysis. Demography and Social Economy. 2 (33), 27-37 (2018)

14. Chernyak, O., Chernyak, Y.: Modern challenges in governmental regulation of labor force migration in Ukraine. Ekonomika. 91 (1), 93-104 (2012)

15. World Migration Report 2018. IOM, Geneva (2017)

16. International Migration Report 2017. UNDESA, New York (2017)

17. World Migration Report 2010. The Future of Migration: Building Capacities for Change. IOM, Geneva (2010)

18. World Bank. Migration and Remittances Factbook 2016. World Bank, Washington, DC (2016)

19. Gonzalez-Barrera, A.: More Mexicans Leaving Than Coming to the U.S. Pew Research Center, Washington (2015)

20. World Migration Report 2013 - Migrant Well-being and Development. IOM, Geneva (2013)

21. Chernyak, O., Chernyak, Y.: "The Golden Migrant Concept" in Governmental Regulation of the Labor Force Migration. Studia Securitatis. VIII(1), 118$122(2014)$ 